\title{
mTORC2/Rictor Signaling Disrupts Dopamine-Dependent Behaviors via Defects in Striatal Dopamine Neurotransmission
}

\author{
Olga I. Dadalko, ${ }^{1,5}$ Michael Siuta, ${ }^{1}$ Amanda Poe, ${ }^{2}$ Kevin Erreger, ${ }^{2}$ Heinrich J.G. Matthies, ${ }^{2}$ Kevin Niswender,, $3 \star$ \\ and Aurelio Galli ${ }^{1,2,5 *}$ \\ ${ }^{1}$ Vanderbilt Brain Institute, ${ }^{2}$ Department of Molecular Physiology \& Biophysics, ${ }^{3}$ Department of Medicine, ${ }^{4}$ Tennessee Valley Healthcare System, and \\ ${ }^{5}$ Neuroscience Program in Substance Abuse, Vanderbilt University School of Medicine, Nashville, Tennessee 37232-8548
}

Disrupted neuronal protein kinase B (Akt) signaling has been associated with dopamine (DA)-related neuropsychiatric disorders, including schizophrenia, a devastating mental illness. We hypothesize that proper DA neurotransmission is therefore dependent upon intact neuronal Akt function. Akt is activated by phosphorylation of two key residues: Thr308 and Ser473. Blunted Akt phosphorylation at Ser473 (pAkt-473) has been observed in lymphocytes and postmortem brains of schizophrenia patients, and psychosis-prone normal individuals. Mammalian target of rapamycin (mTOR) complex 2 (mTORC2) is a multiprotein complex that is responsible for phosphorylation of Akt at Ser473 (pAkt-473). We demonstrate that mice with disrupted mTORC2 signaling in brain exhibit altered striatal DA-dependent behaviors, such as increased basal locomotion, stereotypic counts, and exaggerated response to the psychomotor effects of amphetamine (AMPH). Combining in vivo and ex vivo pharmacological, electrophysiological, and biochemical techniques, we demonstrate that the changes in striatal DA neurotransmission and associated behaviors are caused, at least in part, by elevated D2 DA receptor (D2R) expression and upregulated ERK1/2 activation. Haloperidol, a typical antipsychotic and D2R blocker, reduced AMPH hypersensitivity and elevated pERK1/2 to the levels of control animals. By viral gene delivery, we downregulated mTORC2 solely in the dorsal striatum of adult wild-type mice, demonstrating that striatal mTORC2 regulates AMPH-stimulated behaviors. Our findings implicate mTORC2 signaling as a novel pathway regulating striatal DA tone and D2R signaling.

Key words: Akt; amphetamine; D2 receptor; dopamine; Rictor; transporter

\section{Introduction}

Impaired brain dopamine (DA) homeostasis is strongly implicated in neuropsychiatric disorders, such as schizophrenia and psychostimulant abuse (Narendran and Martinez, 2008; Howes and Kapur, 2009; Espana and Jones, 2013; Nestler, 2013). Evidence from studies in animal models supports the key role of insulin resistance in aberrant striatal DA signaling (Wang et al., 2001, 2002; Johnson and Kenny, 2010; Daws et al., 2011; Niswender et al., 2011; Speed et al., 2011a).

In the CNS, insulin signaling regulates reward, development, and cognition (Schulingkamp et al., 2000; Daws et al., 2011). Importantly, insulin activates intracellular kinases, including Akt (van der Heide et al., 2006). Three isoforms of Akt have been identified and their brain expression characterized. Seminal findings revealed a strong correlation between genetic variants of Akt1 and schizophrenia (Emamian et al., 2004; Nicodemus et al.,

Received March 6, 2015; revised April 24, 2015; accepted April 29, 2015.

Author contributions: 0.I.D., K.N., and A.G. designed research; 0.I.D., M.S., A.P., K.E., and H.J.G.M. performed research; 0.I.D. analyzed data; $0 . I . D .$, K.N., and A.G. wrote the paper.

This work was supported by National Institutes of Health Grant DA038058 to A.G. We thank Dr. Gurevich for superb intellectual support.

The authors declare no competing financial interests.

*K.N. and A.G. contributed equally to this work.

Correspondence should be addressed to Dr. Aurelio Galli, Vanderbilt University School of Medicine, 465 21st Avenue South, Room 7124, MRB III, Nashville, TN 37232-8548. E-mail: aurelio.galli@vanderbilt.edu.

DOI:10.1523/JNEUROSCI.0887-15.2015

Copyright $\odot 2015$ the authors $\quad 0270-6474 / 15 / 358843-12 \$ 15.00 / 0$
2008, 2010; Tan et al., 2012), a DA-associated neuropsychiatric disorder (Howes and Kapur, 2009). Thus, it has been proposed that brain DA dysfunction could stem from altered Akt signaling (Niswender et al., 2011). Recently, we and others have shown that aberrant brain Akt function stemming from either an obesogenic diet or diabetes results in impaired striatal DA homeostasis contributing to DA-dependent behaviors (Williams et al., 2007; Speed et al., 2011b). However, the molecular mechanisms linking Akt dysfunction with altered DA neurotransmission have yet to be established.

Mammalian target of rapamycin (mTOR) complex 2 (mTORC2) is a multiprotein complex that is a critical regulator of cell growth and metabolism. mTORC2 contains Rictor, mSIN1, mLST8, and mTOR. Akt, along with other kinases, is a primary substrate of mTORC2, which is responsible for phosphorylation of Akt at Ser473 (pAkt-473), one of two key phosphorylation sites. To study how aberrant mTORC2 signaling influences central DA neurotransmission, we used Cre-LoxP technology to disrupt the mTORC2 complex by neuronal ablation of the Rictor protein (nRictor KO mouse model) (Shiota et al., 2006; Siuta et al., 2010). We show that impaired mTORC2/ Akt signaling alters striatal DA tone and increases basal and AMPH-induced locomotion and stereotypic counts. These behaviors, traditionally associated with elevated striatal DA signaling (Sharp et al., 1987; Rebec, 2006; Kreitzer and Malenka, 2008), were associated instead with diminished striatal DA bioavailabil- 
ity. Furthermore, viral-mediated recombination specifically in dorsal striatum supports the hypothesis that this brain region has a major role in mediating DA-driven behavioral dysfunction in response to aberrant mTORC2 signaling and possibly Akt Ser473 phosphorylation.

\section{Materials and Methods}

All procedures were performed according to Vanderbilt University Institutional Animal Care and Use Committee approved procedures.

Generation of mice. Mice were engineered as described previously (Siuta et al., 2010). Briefly, mice with floxed Rictor alleles were crossed to Nestin-Cre transgenic animals to produce neuron specific Rictor knockout mice (rictor f/f Nes $+/+$ or $+/-$; nRictor KO). Control mice (CTR) were littermates that lacked Cre recombinase. All mice were backcrossed to C57BL6 background for at least 10 generations. To genotype the animals, DNA from tail clippings was analyzed by PCR with primers for the floxed, nestin, and recombined alleles as previously described (Shiota et al., 2006).

Brain slice preparation and biotinylation. For brain slice preparation and biotinylation, all procedures were performed as previously described (Robertson et al., 2010). Briefly, 8- to 30-week-old mice were killed by rapid decapitation, and corticostriatal $(300 \mu \mathrm{m})$ slices were prepared with a vibratome (Leica, VT1000S) in ice-cold oxygenated $\left(95 \% \mathrm{O}_{2} / 5 \%\right.$ $\mathrm{CO}_{2}$ ) sucrose solution (sucrose $210 \mathrm{~mm} ; \mathrm{NaCl} 20 \mathrm{~mm} ; \mathrm{KCl} 2.5 \mathrm{~mm} ; \mathrm{MgCl}_{2}$ $1 \mathrm{~mm} ; \mathrm{NaH}_{2} \mathrm{PO}_{4} \cdot \mathrm{H}_{2} \mathrm{O} 1.2 \mathrm{~mm}$ ). Slices were then collected in oxygenated artificial CSF (ACSF) ( $\mathrm{NaCl} 125 \mathrm{~mm}, \mathrm{KCl} 2.5 \mathrm{~mm}, \mathrm{NaH}_{2} \mathrm{PO}_{4} \cdot \mathrm{H}_{2} \mathrm{O} 1.2$ $\mathrm{mM}, \mathrm{MgCl}_{2} 1 \mathrm{~mm}, \mathrm{CaCl}_{2} \cdot 2 \mathrm{H}_{2} \mathrm{O} 2 \mathrm{mM}$ ), washed twice with oxygenated $4^{\circ} \mathrm{C}$ ACSF, and then incubated with $4^{\circ} \mathrm{C}$ ACSF solution containing $1 \mathrm{mg} / \mathrm{ml}$ of EZ-Link Sulfo-NHS-SS-Biotin (Pierce/Thermo Scientific) for $45 \mathrm{~min}$. After biotin incubation, the slices were rinsed, washed, and the reaction terminated with ACSF-containing glycine. Dorsal striatum slices from CTR and nRictor $\mathrm{KO}$ mice were anatomically paired, dissected on ice, and frozen at $-80^{\circ} \mathrm{C}$ until use. After homogenization, biotinylated (surface proteins) fraction was isolated with ImmunoPure immobilized streptavidin beads (Pierce). Total slice lysates and biotinylated fractions underwent immunodetection for DA transporter (DAT) and DA D2 receptor (D2R).

Tissue harvest: monoamine, metabolites, and amphetamine (AMPH) content. Mice ( $8-30$ weeks old) were killed by rapid decapitation under volatile isoflurane anesthesia; brains were removed and chilled on ice. Dorsal striatum was dissected out from two hemispheres to create comparable samples for both monoamine content and immunoblotting. After dissection, tissue was frozen on dry ice and stored in $-80^{\circ} \mathrm{C}$ until use. Monoamine content was determined at the Vanderbilt University Neurochemistry Core via high performance liquid chromatography (HPLC) with amperometric detection as described previously (Robertson et al., 2010). To evaluate AMPH concentration in the dorsal striatum, procedures as above were followed in mice injected with $2 \mathrm{mg} / \mathrm{kg}$ AMPH intraperitoneally 30 min before decapitation.

Immunoblotting. Tissue was lysed in 1\% Triton lysis buffer $(25 \mathrm{~mm}$ HEPES, 150 mм NaCl, 2 mм sodium orthovanadate, 2 mм NaF, plus a mixture of protease inhibitors and phosphatase inhibitors) and centrifuged at $17,000 \times g$ for $30 \mathrm{~min}$ at $4^{\circ} \mathrm{C}$. Supernatant was collected into $0.1 \%$ Triton pulldown buffer ( $25 \mathrm{~mm}$ HEPES, $150 \mathrm{~mm} \mathrm{NaCl}, 2 \mathrm{~mm}$ sodium orthovanadate, $2 \mathrm{~mm} \mathrm{NaF}$, plus a mixture of protease inhibitors and phosphatase inhibitors). Protein concentration was determined using Bio-Rad protein concentration kit, and all samples were equalized for total protein amount. Proteins were denatured with SDS-PAGE sample loading buffer at $95^{\circ} \mathrm{C}$ for $5 \mathrm{~min}$, cooled to room temperature, and separated by $10 \%$ SDS-PAGE. Resolved proteins were then transferred to PVDF membrane and blocked in either $5 \%$ milk or $2.5 \%$ BSA in $0.1 \%$ Tween 20 Tris-buffered saline. Blots were then incubated in primary antibody rocking either at room temperature for $1 \mathrm{~h}$ or overnight at $4^{\circ} \mathrm{C}$. The primary antibodies used in this study included Akt (1:1000, Cell Signaling Technology), phospho-Akt serine 473 (pAkt-Ser473) (1:800, Cell Signaling Technology), D2R (1:100; Santa Cruz Biotechnology), D1 DA receptor (1:500; Sigma-Aldrich), tyrosine hydroxylase (1:1000; Cell Signaling Technology), phospho-tyrosine hydroxylase serine 31 (1:800;
Cell Signaling Technology), DAT (1:1000; Dr. Roxanne Vaughan, University of North Dakota School of Medicine, Grand Forks, North Dakota), ERK 1/2 (1:1000; Promega), phospho-ERK 1/2 (1:800; Promega), $\beta$-actin (used as a loading control; 1:1000; Sigma-Aldrich), Na-K ATPase (used as a control for biotinylation; 1:1000; DSHB, Department of Biology, John Hopkins University). All proteins were detected using HRPconjugated secondary antibodies (1:4000; Santa Cruz Biotechnology). After chemiluminescent visualization (PerkinElmer) on Hyblot CL film (Denville Scientific), protein band densities were quantified using ImageJ software (ImageJ, National Institutes of Health, Bethesda, MD).

Ex vivo DA uptake. Corticostriatal slices were prepared as described above. After collection, slices were allowed to recover in $28^{\circ} \mathrm{C}$ oxygenated ACSF for $1 \mathrm{~h}$. The slices were then placed into $37^{\circ} \mathrm{C}$ ACSF uptake buffer for $10 \mathrm{~min}\left(\mathrm{NaCl} 125 \mathrm{~mm}, \mathrm{KCl} 2.5 \mathrm{~mm}, \mathrm{NaH}_{2} \mathrm{PO}_{4} \cdot \mathrm{H}_{2} \mathrm{O} 1.2 \mathrm{~mm}, \mathrm{MgCl}_{2} 1\right.$ $\mathrm{mm}, \mathrm{CaCl}_{2} \cdot 2 \mathrm{H}_{2} \mathrm{O} 2 \mathrm{~mm}, \mathrm{pH}$ 7.4) containing $\left[{ }^{3} \mathrm{H}\right]-\mathrm{DA}$ ( $50 \mathrm{~nm}$ ). Immediately after uptake, slices were washed in ice-cold ACSF three times, homogenized in $1 \%$ Triton lysis buffer (see Immunoblotting), and spun down at $17,000 \times g$ for $30 \mathrm{~min}$ at $4^{\circ} \mathrm{C}$. Supernatant was collected into $0.1 \%$ Triton pulldown buffer, and samples equalized for total protein concentration. Ecoscint H scintillation solution (National Diagnostics) was added to samples and they were quenched overnight, after which radioactivity was measured. Specific uptake was defined as total uptake minus uptake obtained in the presence of $10 \mu \mathrm{M}$ cocaine (nonspecific uptake).

Locomotor behavior. Male mice (8-12 weeks old) were housed in temperature- and humidity-controlled rooms and kept on a $12 \mathrm{~h} \mathrm{light/}$ dark cycle. Food and water were available ad libitum. Experiments were conducted in accordance with the National Institutes of Health guidelines for the care and use of animals and were approved by the Vanderbilt University Institutional Animal Care and Use Committee. Initial handling lasted $5 \mathrm{~d}$, with daily intraperitoneal saline injections. On day 6 , mice were tested for open field locomotor activity. Four-hour-long sessions were performed using automated experimental chambers $(27.9 \times$ $27.9 \mathrm{~cm}$; MED-OFA-510; MED Associates) under constant illumination in a sound-attenuated room. During days $7-12$, mice were habituated to the chambers and saline injections: $4 \mathrm{~h}$ sessions with two saline injections daily (at times $-120 \mathrm{~min}$ and $0 \mathrm{~min}$ ). On day 13 , mice were injected with saline at time $-120 \mathrm{~min}$ and allowed to explore the chambers for $2 \mathrm{~h}$ to settle to comparable baseline. At time $0 \mathrm{~min}$, drugs or vehicle were administered intraperitoneally (AMPH $2 \mathrm{mg} / \mathrm{kg}$; haloperidol $0.8 \mathrm{mg} / \mathrm{kg}$ in DMSO) and locomotion recorded for the next $2 \mathrm{~h}$. Analysis of open field activity, as well as stereotypic counts, was performed using Activity Monitor (MED Associates).

In vivo microdialysis. Mice under anesthesia with isoflurane were placed in a stereotaxic frame (Kopf Instruments) with a mouse adapter. A guide cannula (CMA7 microdialysis) was placed above the dorsal striatum (1.4 anteroposterior, \pm 1.4 mediolateral from bregma, and -0.9 dorsoventral from dura for CTR mice, and 1.0 anteroposterior, \pm 1.4 mediolateral from bregma, and -0.3 dorsoventral from dura for nRictor $\mathrm{KO}$ mice) and secured to the skull with epoxy adhesive (Plastics One). Animals were allowed $24 \mathrm{~h}$ to recover from the surgery. One day before the experiment, animals were placed in individual dialysis chambers, and the microdialysis probe (CMA7 microdialysis) with the active length of 2 $\mathrm{mm}$ was inserted into the guide cannula. One end of a tether (Plastics One) was attached to a harness and the other end attached to a swivel (Instech) mounted on a counterbalanced arm above the dialysis chamber. The probe was perfused overnight at a flow rate of $0.5 \mu \mathrm{l} / \mathrm{min}$ with artificial CSF containing $149 \mathrm{~mm} \mathrm{NaCl}, 2.8 \mathrm{~mm} \mathrm{KCl}, 1.2 \mathrm{~mm} \mathrm{CaCl}, 1.2$ $\mathrm{mm} \mathrm{MgCl}_{2}, 5.4 \mathrm{~mm}$ D-glucose, $\mathrm{pH}$ 7.2. On the day of the experiment, the flow rate was changed to $1.0 \mu \mathrm{l} / \mathrm{min}$ and after equilibration, dialysis fractions (20 min each) were collected to establish baseline concentrations of neurotransmitter efflux. Dialysate samples were stored at $-80^{\circ} \mathrm{C}$ and analyzed by HPLC-EC for DA levels. Probe placement was verified after collection of slices.

Ex vivo high-speed chronoamperometry. Corticostriatal slices were prepared and allowed to recover as specified above for DA uptake. DA concentration was measured by chronoamperometry in the dorsal striatum as previously described (Hoffman and Gerhardt, 1999; Gerhardt and Hoffman, 2001). Briefly, carbon fiber electrodes (100 $\mu$ m length $\times 30$ $\mu \mathrm{m}$ O.D.) coated with nafion for dopamine selectivity were lowered into 
the dorsolateral portion of the striatum so that the tip of the recording electrode was positioned at a depth of $75-100 \mu \mathrm{m}$. The voltage was stepped from 0 to $550 \mathrm{mV}$ for $100 \mathrm{~ms}$ and then back to $0 \mathrm{mV}$, and the charging current of the carbon fiber electrode was allowed to decay for 20 $\mathrm{ms}$ before the signals were integrated. Data were collected at a frequency of $1 \mathrm{~Hz}$ with an Axopatch 200B amplifier. The integrated charge was converted to dopamine concentration based on in vitro calibration with dopamine.

Radioactive nemonapride binding. Dorsal striatum tissue was harvested as described and stored at $-80^{\circ} \mathrm{C}$ until processed. To quantitatively assess D2R expression, plasma membranes were obtained by tissue homogenization in 10 volumes of ice-cold $50 \mathrm{~mm}$ Tris- $\mathrm{HCl}$ buffer (containing also $1 \mathrm{~mm}$ EDTA, $5 \mathrm{~mm} \mathrm{MgCl}, 1.5 \mathrm{~mm} \mathrm{CaCl}_{2}, 120 \mathrm{~mm} \mathrm{NaCl}, 5 \mathrm{~mm} \mathrm{KCl}$, $\mathrm{pH}$ 7.4), and then centrifuged at $40,000 \times g$ for $30 \mathrm{~min}$. The pellet was resuspended in ice-cold $50 \mathrm{~mm}$ Tris- $\mathrm{HCl}$ buffer (containing $1 \mathrm{~mm}$ EDTA, $5 \mathrm{~mm} \mathrm{MgCl}_{2}, 1.5 \mathrm{~mm} \mathrm{CaCl}_{2}, 120 \mathrm{~mm} \mathrm{NaCl}, 5 \mathrm{~mm} \mathrm{KCl}, 12 \mu \mathrm{M}$ pargyline, $0.1 \%$ ascorbic acid, $\mathrm{pH} 7.4$ ), after which protein content was determined by Bradford method. Samples were diluted to the same final protein concentration.

D2R binding assay was performed on ice, using $1.5 \mathrm{~nm}\left[{ }^{3} \mathrm{H}\right]$ nemonapride to determine $\mathrm{V}_{\max }$. Nonspecific binding was determined using $10 \mu \mathrm{M}$ sulpiride. For the ligand-binding assays, the membrane preparations were incubated on a shaker (to prevent precipitation of the membranes) for $60 \mathrm{~min}$ in a final volume of $200 \mu \mathrm{l}$. The reaction was stopped by rapid filtration through Whatman GF/A glass fiber filters. Filters were washed twice with $5 \mathrm{ml}$ of ice-cold $50 \mathrm{~mm}$ Tris-HCl buffer, and, after an overnight incubation, assayed for radioactivity on a liquid scintillation counter. Ligand binding was determined by average of duplicates with subtraction of nonspecific binding, which was observed in the presence of $10 \mu \mathrm{M}$ sulpiride $(30 \%-35 \%)$.

Stereotactic surgeries and viral injections. Mice were anesthetized with isoflurane and placed in a stereotaxic frame (Kopf Instruments) with subsequent injection into two striatal locations. The tip of a $5.0 \mu \mathrm{l} \mathrm{Ham-}$ ilton microsyringe needle (30 gauge) was inserted to stereotaxic coordinates relative to bregma: anteroposterior $0.75 \mathrm{~cm}$; mediolateral \pm 1.50 $\mathrm{cm}$; and dorsoventral $-3.57 \mathrm{~cm}$, and second dorsoventral coordinate, $-3.00 \mathrm{~cm}$. Viral vector suspension in a volume of $1.5 \mu \mathrm{l}$ per hemisphere $(0.750 \mu \mathrm{l}$ into each dorsoventral site) was injected at $0.15 \mu \mathrm{l} / \mathrm{min}$. After microinjection, the needle was left for $3 \mathrm{~min}$ before withdrawal to reduce the efflux of injectate along the injection tract. Mice were excluded from injection failures. For the biochemical assessment, the mice were injected with recombinant adeno-associated viral vectors ( $\mathrm{rAAV}$ )-Cre into the right hemisphere, and with rAAV-eGFP into the left as control. Animals were killed 3 weeks after microinjection, and analysis of the dorsal striatum tissue was performed as described above. For the behavioral experiments, mice were injected bilaterally with either rAAV-Cre or rAAV-eGFP, and locomotor behavior and AMPH-induced hyperactivity were assessed as described above.

Statistical analysis. All data are expressed as the mean \pm SEM. Mean differences between groups were determined using Student's $t$ test or two-way ANOVAs followed by post hoc testing when the main effect or interaction was significant at $p<0.05$. Statistical analyses were conducted using GraphPad Prism. The number of animals and specific statistical analyses used in each experiment are indicated in the text.

\section{Results}

Neuronal deletion of Rictor results in impaired Akt Ser473 phosphorylation and increased DA transporter expression and function in the dorsal striatum

Akt is a serine/threonine protein kinase, whose activity and substrate selectivity are regulated by phosphorylation at two key residues: Thr308 by phosphoinositide-dependent kinase-1, PDK1, and Ser 473 by mTORC2. Rictor, rapamycin-insensitive companion of mTOR, is the scaffolding protein that maintains mTORC2 integrity, allowing for its kinase activity. nRictor $\mathrm{KO}$ mice were generated by crossing floxed Rictor animals with nestin-Cre transgenic mice, as previously described (Siuta et al., 2010). We have shown that nRictor $\mathrm{KO}$ mice lack both rictor mRNA and protein expression in a gene dosage-dependent manner within the brain (Siuta et al., 2010). Figure 1A (inset) reveals a lack of Akt Ser473 phosphorylation in the dorsal striatum of the nRictor KO animals, whereas total Akt is unchanged. Our laboratory and others have previously shown that Akt function regulates DAT trafficking (Doolen and Zahniser, 2001; Carvelli et al., 2002; Garcia et al., 2005; Franke, 2008; Lute et al., 2008; Speed et al., 2010) and, thereby, DA-related behaviors (Williams et al., 2007; Speed et al., 2011a; Owens et al., 2012). Thus, to understand the role of mTORC2/Akt signaling in DA neurotransmission, we first evaluated DAT surface and total expression in the dorsal striatum of nRictor $\mathrm{KO}$ and control (CTR) animals. Using biotinylation (representative immunoblots are shown in Fig. $1 A$ ), we observed that defects in mTORC2 signaling lead to increased DAT plasma membrane expression (Fig. $1 B ; t_{(12)}=3.3, p \leq 0.01, t$ test) and elevated total expression of DAT (Fig. $1 C ; t_{(15)}=3.1, p \leq 0.01$, $t$ test). The absence of the cytosolic protein tyrosine hydroxylase $(\mathrm{TH})$ in the surface fraction indicates the integrity of the experimental preparation, whereas $\mathrm{Na} / \mathrm{K}$ ATPase serves as a loading control (Fig. 1A). We next sought to determine whether augmented total and membrane DAT expression in nRictor KO mice leads to an increase in DAT function. To quantify DAT function, we assessed $\left[{ }^{3} \mathrm{H}\right]$-DA uptake in acute striatal slices. Consistent with the strong increase in DAT protein expression, nRictor $\mathrm{KO}$ mice exhibited significantly higher $\left[{ }^{3} \mathrm{H}\right]$-DA uptake (Fig. $1 D$; $t_{(16)}=2.9, p \leq 0.01, t$ test $)$.

\section{nRictor KO mice exhibit increased novelty-induced locomotion, stereotypic counts, and exaggerated response to AMPH}

DA reuptake by the DAT is the primary mechanism of terminating DA transmission in the dorsal striatum, shaping the duration and amplitude of DA signaling (Kristensen et al., 2011). DA neurotransmission is essential for initiation and organization of motor function (Birkmayer and Hornykiewicz, 1961; Hornykiewicz, 1966; Cotzias et al., 1967; Fischer and Heller, 1967; Ungerstedt, 1968; Ungerstedt and Pycock, 1974; Goldstein et al., 1975; Langston and Ballard, 1983); therefore, DAT function is critical in DA-dependent behaviors, such as locomotor activity. Thus, we determined whether changes in DAT expression and function translate to altered DA-dependent behaviors in nRictor KO mice.

First, we examined basal locomotion. After $5 \mathrm{~d}$ of handling (see Materials and Methods), animals were placed in open field chambers and allowed to freely explore. Locomotor activity was measured as distance traveled in 5 min bins. Compared with CTR, nRictor $\mathrm{KO}$ mice exhibit a dramatic and stable increase in horizontal locomotion ( $n=12$, two-way ANOVA, effect of genotype, $F_{(1,528)}=1492, p<0.0001$; followed by Bonferroni post hoc test; Fig. 2A). Furthermore, stereotypic counts (stereotypic episodes counted in beam breaks within a small 4-beam box) in nRictor KO mice are significantly elevated with respect to CTR animals ( $n=10$, two-way ANOVA, effect of genotype, $F_{(1,648)}=$ 523.8, $p<0.0001$; followed by Bonferroni post hoc test; Fig. $2 B$ ). These data are consistent with the notion that impaired striatal DA neurotransmission contributes to aberrant "stereotypic behaviors" (Kelly et al., 1975; Andrews et al., 1982; Carr and White, 1984; Porrino et al., 1984; Sharp et al., 1987). Mice heterozygous for rictor deletion did not show alterations in locomotor activity or stereotypic counts (data not shown), demonstrating that nestin-Cre transgene has no effect on these DA-associated behaviors. Importantly, this also strongly suggests that the full blockade of mTORC2 signaling is necessary to induce the phenotype observed in the nRictor KO. 

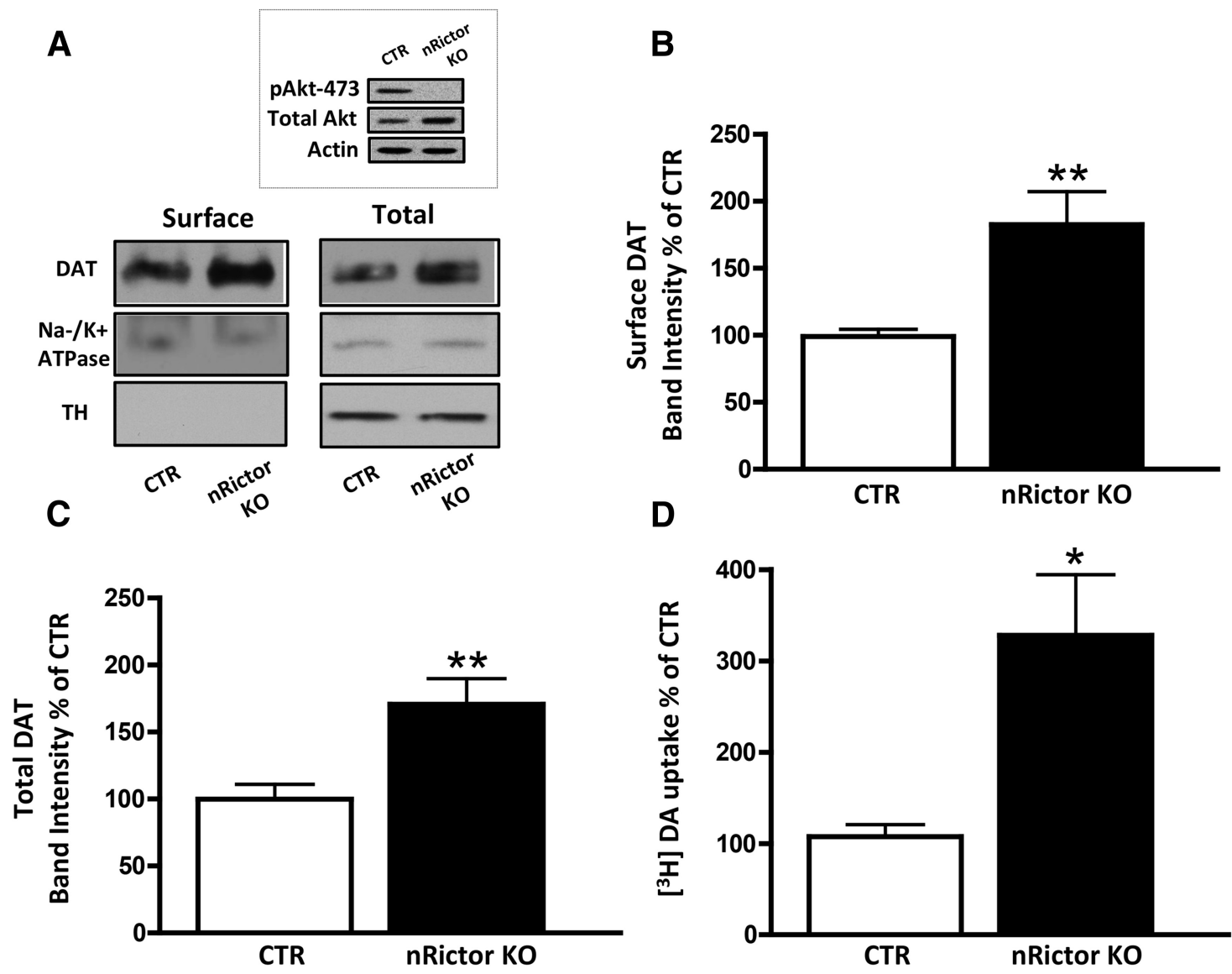

Figure 1. DAT expression and function are increased in the dorsal striatum of the nRictor KO mouse. $A$, Representative immunoblots of surface and total protein fractions probed with a selective anti-DAT antibody or with an anti-Na-K ATPase antibody to serve as a loading control. TH, a cytosolic protein, was detected in the total fraction but not in the biotinylated fraction. Inset, Representative immunoblot of pAkt-473 in the dorsal striatum of nRictor KO mice and CTR animals. B, Quantitation of the optical density of DAT surface fraction normalized to CTR ( $n=13)$. $C$, Quantitation of the optical density of the total protein fraction normalized to $C T R(n=16) \cdot \boldsymbol{D},\left[{ }^{3} \mathrm{H}\right]-$-DA uptake in anatomically paired striatal slices obtained from CTR and $n$ Rictor K0 mice expressed as a percentage of control $(n=18) .{ }^{*} p<0.05$ ( $t$ test). ${ }^{* *} p<0.01$ ( $t$ test).

AMPH exerts its action mainly via DAT, causing nonvesicular DAT-mediated DA efflux (Kahlig et al., 2005; Sulzer et al., 2005). The observed increase in DAT expression in the dorsal striatum of the nRictor $\mathrm{KO}$ mice allowed us to hypothesize that AMPH would cause exaggerated behavioral responses in nRictor $\mathrm{KO}$ animals. Consistent with this hypothesis, mice that overexpress DAT (DAT-tg), as well as animals with an increased DAT surface expression $\left(\mathrm{Gpr} 37^{-1-}\right.$ ) exhibit exaggerated AMPH-induced hyperlocomotion (Marazziti et al., 2004; Salahpour et al., 2008). To evaluate changes in the locomotor response caused by AMPH in nRictor KO mice, a 6-day-long habituation protocol (see Materials and Methods) was empirically used to decrease the basal locomotion of the nRictor KO to the level of CTR mice. On the test day (day 7), an initial saline injection was followed by a $2 \mathrm{~h}$ period in the chamber, a sufficient time for all animals to reach comparable baseline locomotion. AMPH ( $2 \mathrm{mg} / \mathrm{kg})$ was then administered intraperitoneally (time 0 ), and horizontal locomotion was recorded in $5 \mathrm{~min}$ bins for the next $2 \mathrm{~h}$. nRictor $\mathrm{KO}$ animals demonstrate exaggerated psychomotor response to AMPH, with locomotor activity markedly higher than that of CTR animals (two-way ANOVA, effect of genotype, $F_{(1,198)}=71.15, p<$ 0.0001; followed by Bonferroni post hoc test; Fig. 2C). The AMPH tissue content in the dorsal striatum of the nRictor KO mouse is comparable with the CTR animals (Fig. $2 D ; t_{(4)}=2.7, p>0.05$, $t$ test) and, importantly, is clearly not elevated relative to CTR, indicating that AMPH transport across the blood-brain barrier is not altered by Rictor deletion.

DAT expression and cellular distribution are precisely regulated, and alterations in DAT availability could contribute to DA dysfunction and to the pathophysiology of neuropsychiatric disorders. However, clinical studies have not been consistent on this issue, showing increased, decreased, or no change in striatal DAT availability in patients with schizophrenia (Brunelin et al., 2013). We have shown that decreased brain mTORC2 signaling also results in deficits in prepulse inhibition (Siuta et al., 2010). Here, we demonstrate that elevated striatal surface and total DAT support AMPH hypersensitivity. Psychostimulants, including $\mathrm{AMPH}$, cause changes in behavior by elevating striatal DA bioavailability (Rebec, 2006). Thus, our data suggest elevated DA tone in the dorsal striatum of nRictor KO mice. Therefore, our next goal was to determine the neuronal adaptation caused by mTORC2 signaling within the DA network.

nRictor KO mice exhibit reduced AMPH-induced DA release, tissue DA content, and TH phosphorylation

Basal hyperlocomotion and exaggerated locomotor response to AMPH are phenotypes suggestive of striatal DA hyperfunction (Bardo et al., 1990; Rebec, 2006). To further test this, we evaluated AMPH-induced DA release in the dorsal striatum of nRictor $\mathrm{KO}$ mice by in vivo microdialysis and ex vivo chronoamperom- 
A
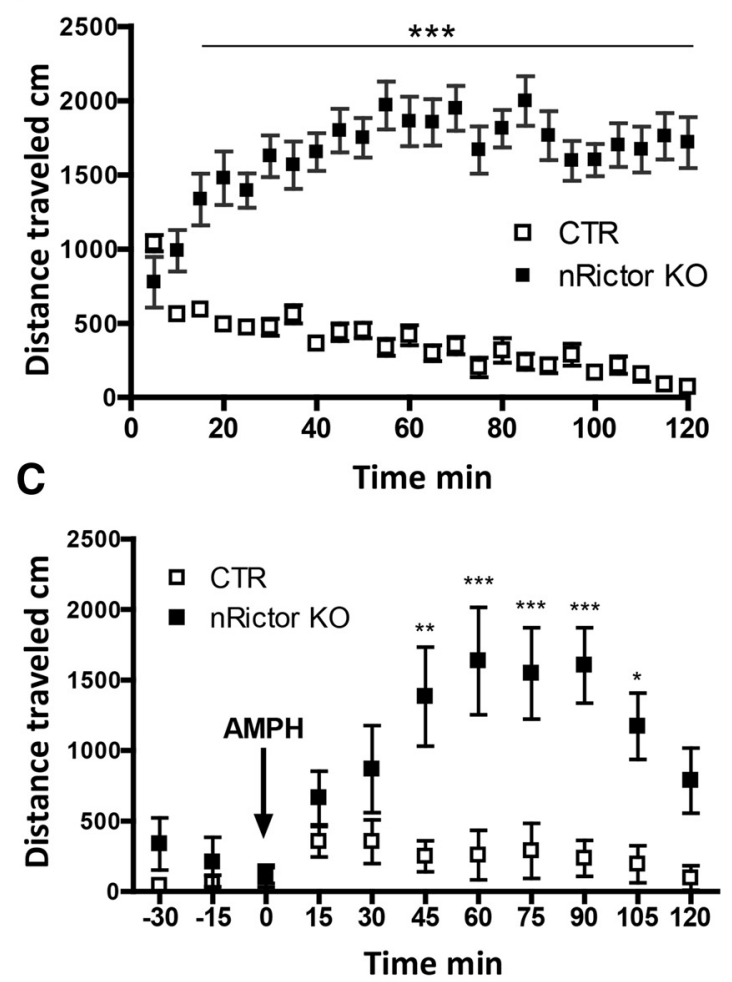

B
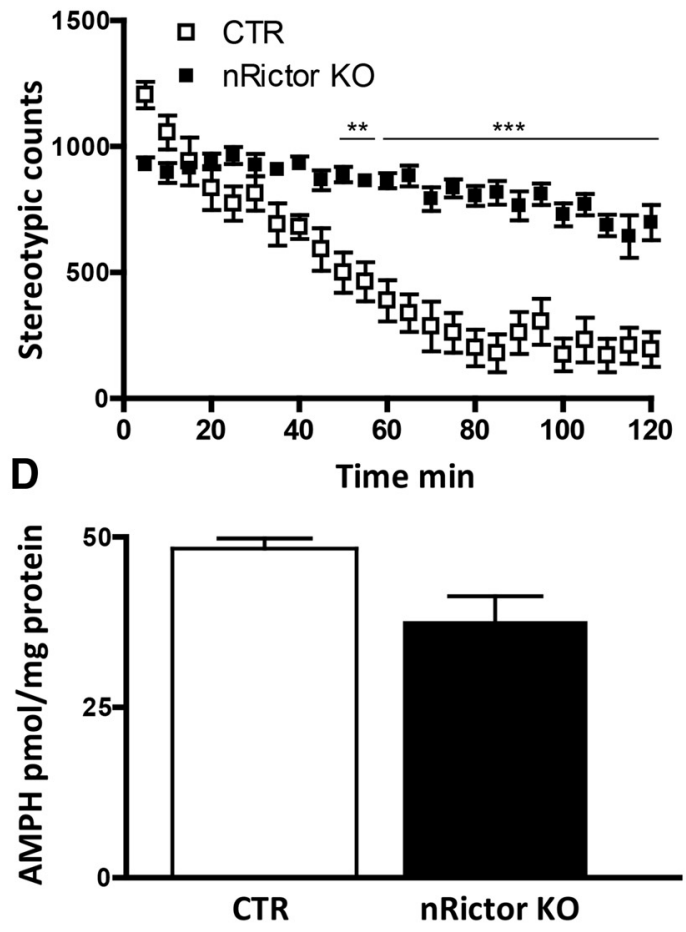

Figure 2. Neuronal deletion of Rictor results in novelty-induced hyperactivity, increased stereotypic counts, and exaggerated locomotor response to AMPH. $\boldsymbol{A}$, Horizontal locomotion measured in open field chambers in 5 min intervals. Shown is the distance traveled in centimeters ( $n=12$ ). $\boldsymbol{B}$, Stereotypic counts binned in 5 min intervals ( $n=10)$. $\boldsymbol{C}$, AMPH ( 2 mg/kg i.p.) stimulated locomotor activity binned in $15 \mathrm{~min}$ intervals $(n=10)$. Both CTR and KO mice were habituated to achieve nonsignificant differences in basal locomotor activity before AMPH injection. Data represent distance traveled in centimeters. D, At 30 min after $2 \mathrm{mg} / \mathrm{kg}$ (i.p.) AMPH, animals were killed, and tissue content of AMPH was measured by HPLC in striatal homogenates. ${ }^{*} p<0.05$ (Bonferroni post hoc test). ${ }^{* *} p<0.01$ (Bonferroni post hoc test). ${ }^{* * *} p<0.001$ (Bonferroni post hoc test).

etry. The nRictor KO mouse has reduced brain size (Siuta et al., 2010) consistent with the phenotype of the Akt3 KO mouse (Easton et al., 2005). Thus, we empirically defined the stereotactic coordinates to ensure accurate and parallel placement of the probe in the nRictor $\mathrm{KO}$ and CTR animals. At $18-24 \mathrm{~h}$ after mice underwent guide cannula placement, microdialysis probes were inserted into the dorsal striatum of nRictor KO and CTR mice. Dialysate samples were collected in $20 \mathrm{~min}$ intervals and analyzed by HPLC for monoamine and metabolite content. After establishing a stable baseline, AMPH was administered (2 mg/kg i.p.). $\mathrm{AMPH}$-induced DA release was significantly reduced in the dorsal striatum of nRictor $\mathrm{KO}$ mice relative to CTR (two-way ANOVA, effect of genotype, $F_{(1,12)}=13.8, p<0.01$; followed by Bonferroni post hoc test; Fig. $3 A$ ).

To confirm this reduction in AMPH-induced DA efflux, we used ex vivo chronoamperometry to measure AMPH-induced DA release directly from striatal slices. Coronal slices with dorsal striatum were recovered in $28^{\circ} \mathrm{C}$ oxygenated aCSF for a minimum of $1 \mathrm{~h}$ before recording. The carbon fiber electrode was angularly deepened into the dorsolateral portion of the striatum (same locale as microdialysis). AMPH $(10 \mu \mathrm{M})$ was bath applied after $30 \mathrm{~min}$ of baseline recordings. In agreement with the microdialysis data, AMPH-induced DA release was significantly reduced in the striatal tissue of the nRictor KO compared with CTR animals (two-way ANOVA, effect of genotype, $F_{(1,410)}=106.4$, $p<0.0001$; followed by Bonferroni post hoc test; Fig. $3 B$ ).

It is possible that the observed decrease in AMPH-induced DA efflux stems from impaired function of $\mathrm{TH}$, the rate-limiting enzyme for DA synthesis. Indeed, it has been shown that $\mathrm{TH}$ inhibition leads to a reduction in psychostimulant-induced DA release, confirming that the newly synthesized pool of DA is essential for AMPH-induced DA efflux (Butcher et al., 1988; Thomas et al., 2008). TH conformation and activity are regulated by four phosphorylation sites. Ser31 is the key residue whose phosphorylation correlates with $\mathrm{TH}$ activity in vivo (Salvatore et al., 2009; Damanhuri et al., 2012; Salvatore and Pruett, 2012). Further, it has been shown that DA levels also correlate with the level of TH phosphorylation at Ser31 (Salvatore, 2014). Thus, we quantified pTH-Ser31 in nRictor KO mice relative to CTR animals. Indeed, phosphorylation of TH at Ser31 is reduced in nRictor $\mathrm{KO}$ mice with respect to CTR animals (Fig. $3 C$; $t_{(12)}=6.0, p<$ $0.001, t$ test). These data reveal a strong association between mTORC2 signaling, TH phosphorylation, and the ability of AMPH to cause DA efflux. In line with the downregulation of pTH-Ser31, we found a reduction in DA and its metabolites in the dorsal striatum tissue of nRictor $\mathrm{KO}$ animals, as well as a consistent increase in tyrosine, the DA precursor (Fig. 3D; DA: $t_{(21)}=2.6$; tyrosine: $t_{(8)}=2.9$; DOPAC: $t_{(22)}=3.6$; HVA: $t_{(21)}=$ $4.7)$.

Elevated striatal expression of D2R and pERK1/2 in nRictor KO mice supports exaggerated AMPH-induced locomotion Basal hyperlocomotion, elevated stereotypic counts, and the ability of AMPH to induce exaggerated hyperactivity are behaviors that rely, at least in part, on increased DA tone in the dorsal striatum (Bardo et al., 1990; Rebec, 2006). However, nRictor KO animals exhibit reduced AMPH-induced DA release (Fig. 3). This is consistent with lowered DA tissue content and attenuated 
A

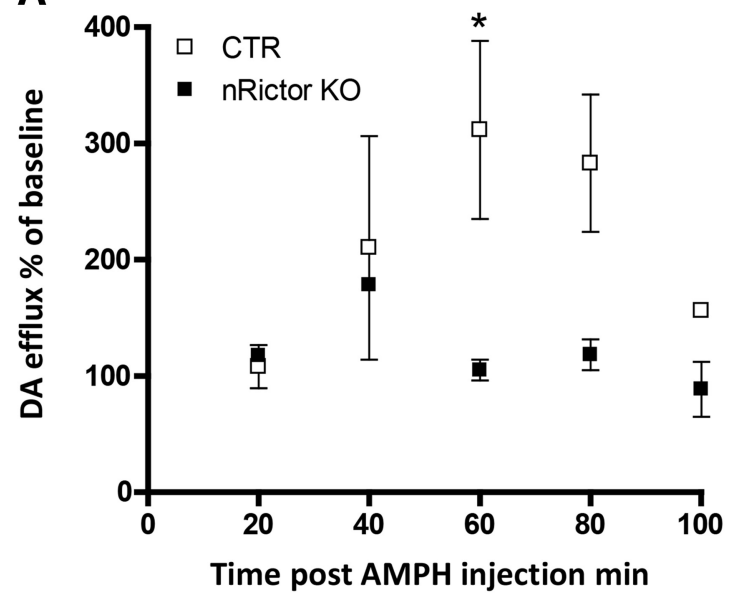

C

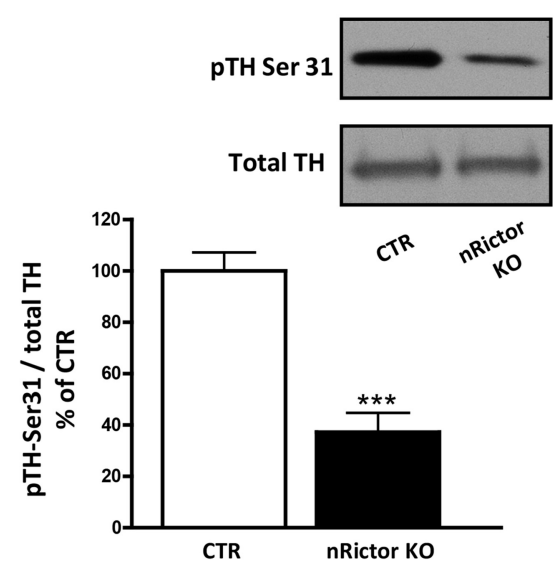

B

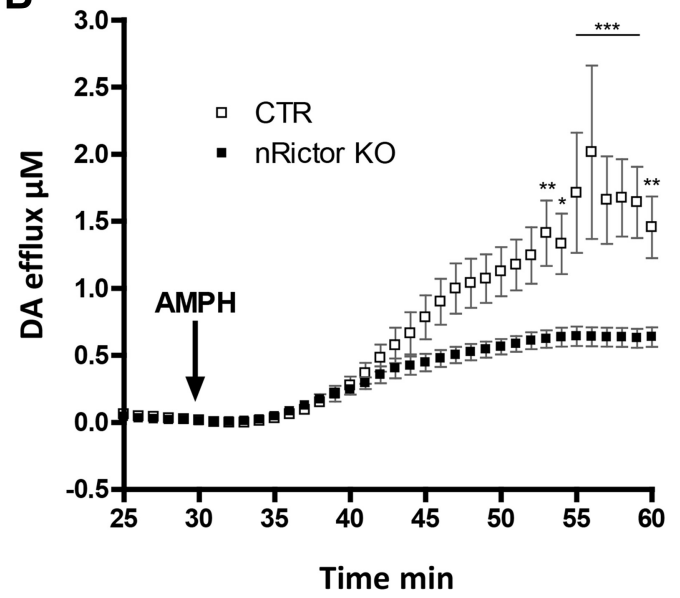

D

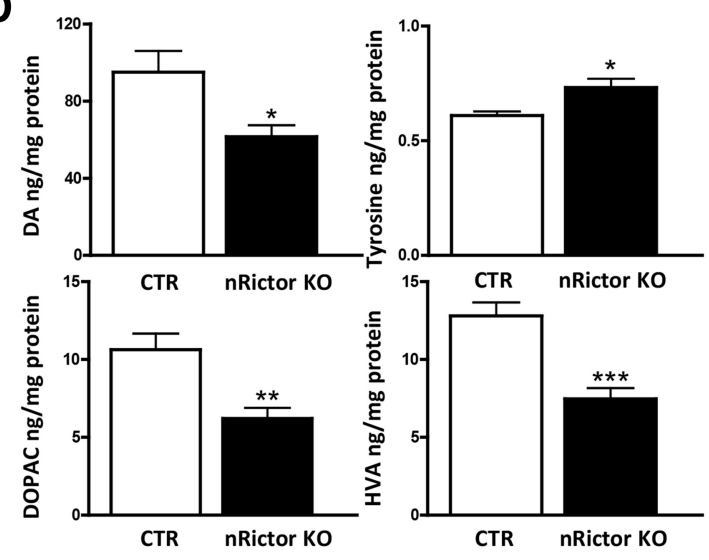

Figure 3. nRictor KO exhibit reduced AMPH-induced DA release, tissue DA content, and TH phosphorylation. $A$, Time course of extracellular DA concentration as measured by microdialysis coupled with HPLC from the dorsal striatum of CTR and nRictor KO mice after intraperitoneal administration of AMPH ( $2 \mathrm{mg} / \mathrm{kg})(n=2)$. Results are shown as percentage of baseline in $20 \mathrm{~min}$ intervals. $\boldsymbol{B}$, AMPH-induced $(10 \mu \mathrm{m})$ DA release measured by oxidation currents from striatal slices reported as $\mu \mathrm{m}$ DA release $(n=6)$. C, Top, pTH-Ser31 and TH representative immunoblots obtained from striatal tissue. Bottom, Quantification of the ratio of pTH-Ser31 to total TH expressed as a percentage of (TR $(n=7)$. D, DA tissue content $(n=11-12)$, its precursor tyrosine $(n=5)$, and its metabolites DOPAC $(n=12)$ and HVA $(n=11-12)$ as measured by HPLC in striatal homogenates. ${ }^{*} p<0.05$ ( $t$ test). ${ }^{* *} p<0.01$ ( $t$ test). ${ }^{* * *} p<0.001$ ( $t$ test).

phosphorylation of TH at Ser31. Thus, it is possible that altered expression and/or function of DA receptors (e.g., D1R and D2R) are involved. In support of this hypothesis are data demonstrating that mice with elevated striatal D2R expression display increased locomotion in a novel environment (Kramer et al., 2011). Further, toxin ablation and functional disruption of D2Rexpressing striatopallidal medium spiny neurons (MSNs) inhibit locomotor activity (Durieux et al., 2009; Bateup et al., 2010). Consistently, we found total protein levels of D2R in the dorsal striatum of nRictor $\mathrm{KO}$ mice to be significantly elevated relative to CTR animals (Fig. $4 A ; t_{(26)}=3.3, p<0.01, t$ test). Surface expression of $\mathrm{D} 2 \mathrm{R}$ determined by slice-surface biotinylation was also significantly increased (CTR $100 \pm 12.7$; nRictor KO $245 \pm$ $49.0 ; t_{(8)}=3.8, p<0.01, t$ test $)$. To corroborate these findings, we isolated plasma membranes from the dorsal striatum tissue and observed elevated $\left[{ }^{3} \mathrm{H}\right]$-nemonapride (a potent D2R antagonist) binding in the nRictor $\mathrm{KO}$ mice, further evidence of increased D2R (Fig. $4 B ; t_{(17)}=1.9, p<0.05, t$ test). Importantly, the levels of D1R in the nRictor KO mice were not significantly different from those of CTR (Fig. $4 C ; t_{(23)}=1.19, p>0.05, t$ test).

Activation of D2R results in enhanced phosphorylation of extracellular signal-related kinase (ERK1/2) (Luo et al., 1998; Cai et al., 2000; Wang et al., 2005; Bolan et al., 2007). The relationship between D2R signaling, ERK1/2 phosphorylation, and locomo- tion has been defined by Cai et al. (2000) who demonstrated that activation of ERK1/2 in DA-deficient dorsal striatum is required for D2R signaling to drive locomotor hyperactivity. Here, we observe that the increase in D2R expression in nRictor KO mice leads to a marked basal increase in striatal pERK1/2 (Fig. $4 D$; $t_{(12)}=3.0, p<0.01, t$ test $)$. To determine the role of $\mathrm{D} 2 \mathrm{R}$ in the hyperlocomotion observed in nRictor $\mathrm{KO}$ mice, we first tested the effect of haloperidol, a typical antipsychotic and D2R antagonist, on ERK1/2 phosphorylation in the dorsal striatum. Haloperidol was administered $(0.8 \mathrm{mg} / \mathrm{kg}$ i.p., a dose of therapeutic relevance) to efficiently block the elevated D2R of nRictor KO mice (Clapcote et al., 2007; Lipina et al., 2010). One hour after injection, mice were killed and dorsal striatal homogenates probed for $\mathrm{pERK} 1 / 2$. In nRictor $\mathrm{KO}$ mice, haloperidol reduced pERK1/2 to CTR levels (Fig. $5 A ; t_{(16)}=1.7, p<0.05, t$ test), indicating that the enhanced $\mathrm{D} 2 \mathrm{R}$ signaling causes increased ERK1/2 phosphorylation in the KO animals. D2R are involved in the symptomology of patients with neuropsychiatric disorders, and human imaging studies show elevated efficacy of DA to stimulate D2R in both drug-naive and treated schizophrenia patients (Abi-Dargham et al., 2000). Next, we determined whether blockade of D2R with haloperidol (administered as above) alters levels of pTH-Ser31 in nRictor $\mathrm{KO}$ animals. In nRictor $\mathrm{KO}$ mice, haloperidol significantly increased levels of $\mathrm{pTH}-\mathrm{Ser} 31$ with respect to 

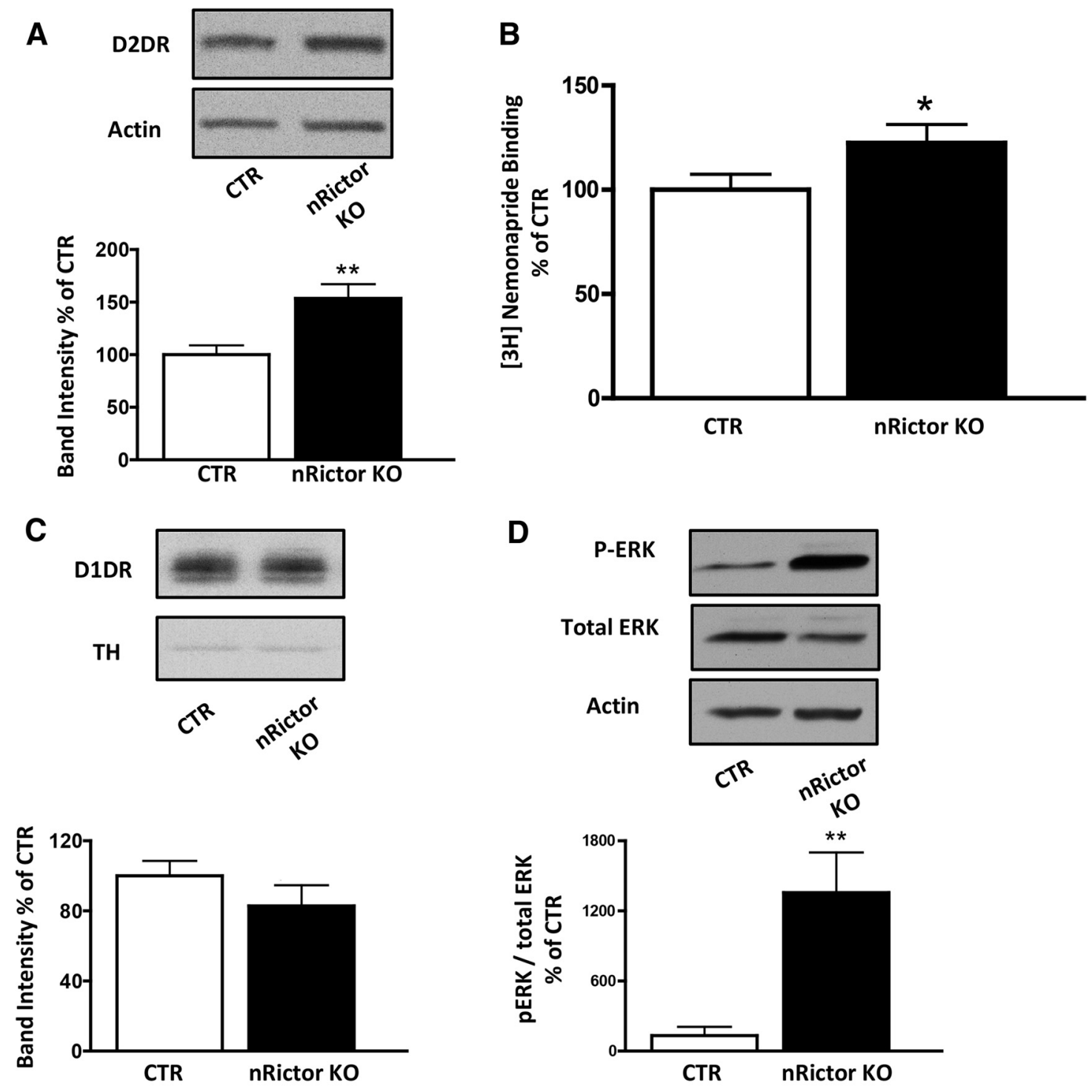

Figure 4. Elevated expression of D2R and not D1R increases pERK1/2 in the nRictor K0 mice. $A$, Representative immunoblots (top) and optical density quantitation (bottom) of D2R expression in the dorsal striatum of nRictor KO and CTR animals. Actin was probed as a loading control. Data are expressed as percentage of CTR $(n=14)$. $\boldsymbol{B},\left[{ }^{3} \mathrm{H}\right]$ Nemonapride binding to striatal plasma membranes of (TR and nRictor KO mice: nonspecific binding (in the presence of $10 \mu \mathrm{m}$ sulpiride) was subtracted from the specific binding, which was counted in duplicates in DPM and averaged within a sample. Data normalized to CTR levels $(n=8)$. C, Representative immunoblots (top) from striatal homogenates obtained from nRictor and CTR mice probed with D1R antibody, and quantitation of the respective optical densities (bottom). Data are shown as a percentage of control. Actin immunoblots served as a loading control $(n=12-13)$. $\boldsymbol{D}$, Representative immunoblot and quantification of pERK1/2 (shown as a percentage of control) and total ERK in the dorsal striatum of (TR and nRictor K0. Actin is the loading control $(n=6-8)$. ${ }^{*} p<0.05$ ( $t$ test). ${ }^{* *} p<0.01$ ( $t$ test).

saline-injected animals (Fig. $5 B ; t_{(16)}=3.9, p<0.01, t$ test). These data indicates that enhanced D2R signaling contributes, a least in part, to the decreased pTH-Ser31 in the KO animals. To further define the role of $\mathrm{D} 2 \mathrm{R}$ in the phenotypes of the nRictor KO mice, we tested whether haloperidol would block the exaggerated response to AMPH in nRictor KO mice. Coadministration of haloperidol with AMPH reversed the exaggerated AMPH-induced hyperactivity of nRictor $\mathrm{KO}$ mice, reducing their locomotor activity to the level of CTR mice (Fig. $5 C$; locomotor activity represented as area under the curve from the time of injection to 60 min, AMPH treatment: $t_{(9)}=2.4, p<0.05, t$ test; AMPH + haloperidol (AMPH Haldol) treatment: $t_{(9)}=1.2, p>0.5, t$ test).

Reduced mTORC2 signaling in the dorsal striatum supports exaggerated AMPH-induced hyperactivity

rAAVs are widely used for temporally and spatially controlled gene delivery. Of many naturally available serotypes, rAAV-5 was shown to be the most efficient for genetic transduction in the dorsal striatum of mice (Aschauer et al., 2013) and nonhuman primates (Markakis et al., 2010). To strengthen our hypothesis that AMPH-induced hypersensitivity of nRictor $\mathrm{KO}$ animals stems, at least in part, from impaired mTORC2 signaling specifically in the dorsal striatum, we selectively deleted Rictor by injecting rAAV-Cre into the dorsal striatum of floxed Rictor mice. For biochemical assessment, floxed Rictor animals were injected unilaterally with rAAV-Cre, whereas the other hemisphere was injected with rAAV-eGFP as a control. Light and fluorescence microscopy confirmed localization of injections to dorsal striatum (Fig. 5D, top). Dorsal striata injected with rAAV-Cre showed a reduction in pAkt-473 compared with rAAV-eGFP injected striata (Fig. 5D, bottom). Four weeks after bilateral rAAV-Cre injection, animals exhibited exaggerated AMPH-induced hyperlocomotion relative to $\mathrm{AAAV}$-eGFP animals (Fig. 5E; locomotor 

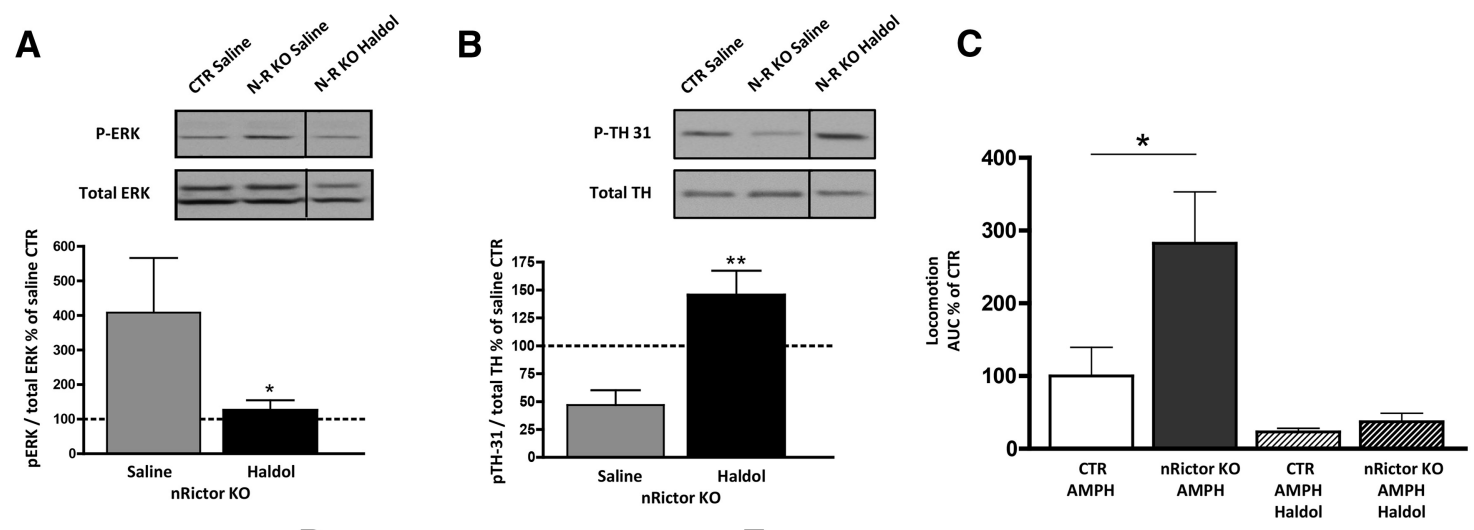

D

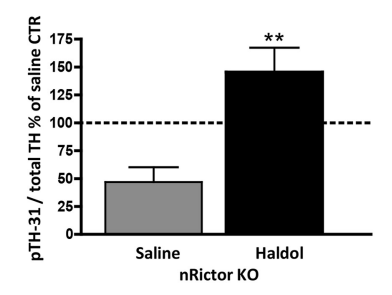

E
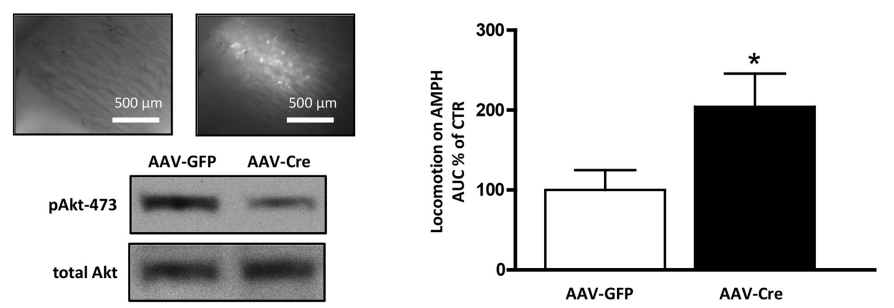

Figure 5. Treatment with haloperidol supports the role of D2R in exaggerated AMPH-induced hyperactivity in nRictor KO mice, whereas viral intervention reveals that Akt signaling specifically in the dorsal striatum supports this phenotype. $A$, Acute administration of haloperidol $(0.8 \mathrm{mg} / \mathrm{kg}$ i.p.) reduced expression of pERK1/2 in the dorsal striatum of nRictor mice. Top, Representative immunoblots for pERK1/2 obtained from striatal tissue of (TR and nRictor mice injected either vehicle or haloperidol (Haldol). Bottom, Data were normalized to saline-injected (TR ( $n=9$ ). $\boldsymbol{B}$, Acute administration of haloperidol $(0.8 \mathrm{mg} / \mathrm{kg}$ i.p.) decreased expression of pTH-Ser31 in the dorsal striatum of nRictor mice. Top, Representative immunoblots for pTH-Ser31 and total TH obtained from striatal tissue of (TR and nRictor mice injected either vehicle or haloperidol (Haldol). Bottom, Data were normalized to the corresponding total TH and expressed as a percentage of saline-injected CTR $(n=9)$. C, CTR and nRictor K0 mice were habituated to saline injections and open field chambers for $6 \mathrm{~d}$. On day 7, drugs were administered intraperitoneally (AMPH $2 \mathrm{mg} / \mathrm{kg}$; haloperidol 0.8 $\mathrm{mg} / \mathrm{kg}$ ) and horizontal locomotor activity recorded in $5 \mathrm{~min}$ intervals. Data are represented as area under the curve from time of injection to $60 \mathrm{~min}(n=5-6)$. D, Viral downregulation of striatal Rictor results in decreased pAkt-473: AAV-Cre-GFP and AAV-eGFP viral vectors were injected into the dorsal striatum of floxed animals. Shown are representative immunoblots of AAV-Cre-injected animals versus AAV-eGFP CTRs. Inset, Representative images ( $4 \times$ ) demonstrating GFP in the targeted brain region: white light on the left; FITC filter on the right. $\boldsymbol{E}$, AMPH (2 mg/kg i.p.) induced locomotion measured following the same handling/habituation protocol as was used for the genetic $K 0$. Data are represented as area under the curve from the time of injection to $60 \mathrm{~min}(n=7)$. ${ }^{*} p<0.05$ ( $t$ test) ${ }^{* *} p<0.01$ ( $t$ test).

activity represented as area under the curve from the time of injection to $60 \mathrm{~min}, t_{(12)}=2.2, p<0.05, t$ test).

\section{Discussion}

The mTORC2 complex is responsible for phosphorylation of AGC kinases to promote their maturation, stability, and allosteric activation (Oh and Jacinto, 2011). These kinases include Akt, serum/glucocorticoid regulated kinase 1, and protein kinase $\mathrm{C} \alpha$. Clinical evidence supports a role for Akt in DA-dependent mental illness (Emamian et al., 2004; Lu and Dwyer, 2005; Krishnan et al., 2008). Nonetheless, the molecular mechanisms linking altered mTORC2/Akt signaling to impaired DA neurotransmission and corresponding behaviors have been elusive. Here, we demonstrate how genetic deletion of Rictor protein and the parallel reduction of pAkt- 473 in the brain results in altered striatal DA tone.

Our laboratory has extensively studied how Akt signaling influences DA tone in the brain (Williams et al., 2007; Speed et al., 2010, 2011a). Our published data reveal that Akt function supports DAT surface expression (Williams et al., 2007; Speed et al., 2010, 2011a). Here we expand upon these findings, demonstrating that genetic deletion of the protein Rictor causes a reduction in Akt Ser473 phosphorylation and an increase in DAT expression. These data are consistent with a differential role of Akt Ser473 phosphorylation and Akt function in DA homeostasis. However, in the current study, we cannot rule out the possibility that other AGC kinases regulated by mTORC2 participate in this process. These data warrant further mechanistic investigation to understand the differential effects that perturbations of the mTORC2 pathway might have on central DA neurotransmission. In this context, it is important to point out seminal work by Mazei-Robison et al. (2011).

Here we show that genetic disruption of mTOR/Rictor signaling in the brain in nRictor KO mice behaviorally manifests in novelty-induced hyperactivity and AMPH hypersensitivity, two phenotypes that have been associated in animal models with schizophrenia (Gainetdinov et al., 2001). These behaviors were mechanistically supported by both presynaptic and postsynaptic changes in the DA system. These include diminished DA bioavailability and elevation in D2R and its downstream signaling. Further, we demonstrate that mTORC2 signaling specifically in the dorsal striatum regulates AMPH-induced locomotion.

Striatum is a basal ganglia nucleus critically involved in integrating motor control, reward, and motivation. It is also implicated in brain disorders, such as Parkinson's and Huntington's disease, drug addiction, and schizophrenia (Nestler, 2005; Kellendonk et al., 2006; Kreitzer and Malenka, 2008; Simpson et al., 2010; Durieux et al., 2012). Studies in animal models link stereotypy to aberrant DA signaling in the dorsal striatum (Kelly et al., 1975; Andrews et al., 1982; Carr and White, 1984; Porrino et al., 1984; Sharp et al., 1987). Our results demonstrate that global brain impairment of mTORC2 signaling results in hyperactivity, increased stereotypy, and exaggerated response to AMPH. A limitation to the genetic approach undertaken here is that nRictor KO mice have reduced brain size (Siuta et al., 2010). Therefore, 
we cannot exclude the possibility that the observed phenotype was influenced by developmental impairment. However, virally mediated deletion of Rictor specifically in the dorsal striatum of adult mice significantly increased the ability of AMPH to stimulate locomotion, recapitulating, at least in part, nRictor $\mathrm{KO}$ mouse behavior. Overall, our data strongly support a primary role for mTORC2 signaling in modulating striatal DA neurotransmission.

AMPH-induced changes in behavior are caused by elevated intrasynaptic DA promoted by nonvesicular DAT-mediated DA release (Fischer and Cho, 1979; Sulzer et al., 2005; Rebec, 2006; Hamilton et al., 2014). Surprisingly, we found a decrease in DA bioavailability in response to AMPH in the dorsal striatum of nRictor KO mice. This finding is further supported by the observed reduction of tissue DA levels, as well as lowered pTHSer31. This key phosphorylation site correlates with $\mathrm{TH}$ activity in vivo and is a reliable predictor of DA tissue content (Salvatore et al., 2009; Damanhuri et al., 2012; Salvatore and Pruett, 2012). Together, these data suggest the involvement of compensatory mechanisms that use DA receptors for the observed behavior. In this respect, the nRictor $\mathrm{KO}$ mouse represents a unique model of aberrant brain mTORC2 signaling causing a plethora of changes in central DA neurotransmission, including altered D2R signaling. The finding that nRictor KO mice have elevated D2R expression, with no change observed in D1R levels, supports this hypothesis.

nRictor KO mice have reduced striatal DA content in the context of elevated D2R. These data are in line with previous studies suggesting that striatal DA depletion leads to an increase in D2R, and not D1R expression (Dewar et al., 1990; Radja et al., 1993). However, we cannot exclude the possibility that overexpression of $\mathrm{D} 2 \mathrm{R}$ drives the reduction in DA content. In support of this mechanistic hypothesis, acute administration of haloperidol increased TH phosphorylation at Ser31 in nRictor KO mice. This key phosphorylation site correlates with $\mathrm{TH}$ activity in vivo and is a reliable predictor of DA tissue content (Salvatore et al., 2009; Damanhuri et al., 2012; Salvatore and Pruett, 2012). We also hypothesize that increased D2R expression drives the nRictor $\mathrm{KO}$ behavioral phenotype. Consistent with this hypothesis, the AMPH locomotor hypersensitivity of these mice was blocked by the $\mathrm{D} 2 \mathrm{R}$ inhibitor haloperidol. The involvement of D2R in the regulation of locomotion is further supported by D2R-eGFP mice, which overexpress D2R in the medium spiny neurons and exhibit higher basal activity (Kramer et al., 2011). Therefore, elevated D2R in this model appears to drive both reduced DA synthesis and hypersensitivity to AMPH.

In nRictor $\mathrm{KO}$ animals with impaired mTORC2 signaling, phosphorylation of ERK1/2 is markedly elevated, a known downstream target of D2R activation (Luo et al., 1998; Cai et al., 2000; Wang et al., 2005; Bolan et al., 2007). Therefore, the observed that increase in $\mathrm{D} 2 \mathrm{R}$ expression in nRictor $\mathrm{KO}$ mice likely accounts for the increase in striatal ERK1/2 phosphorylation. This possibility is strengthened by the finding that haloperidol treatment blocked the exaggerated AMPH-induced hyperlocomotion and lowered ERK1/2 phosphorylation in nRictor KO mice. Prior studies have shown that, in DA-depleted striatum, pERK1/2 was increased in response to D2R, but not D1R stimulation, which led to a characteristic rotating phenotype that could be blocked by the inhibition of the MAPK/ERK pathway (Cai et al., 2000). In addition, a recent study revealed that disruption of upstream activators of the Akt signaling pathway in D2R expressing striatopallidal MSNs results in spontaneous and drug-induced hyperlocomotion along with an increase in ERK1/2 phosphorylation
(Besusso et al., 2013). Together, our data suggest a "cross talk" between mTORC2 function and D2R-ERK1/2 signaling that drives specific DA-dependent dorsal striatum-associated behaviors. Indeed, the significant increase in striatal pERK1/2 was restored to control levels with an acute treatment of haloperidol, a typical antipsychotic and D2R antagonist. Furthermore, our behavior experiments demonstrate that haloperidol blocks the exaggerated AMPH-induced hyperlocomotion in mice with reduced brain mTORC2 signaling.

In this study, we functionally isolate the dorsal striatum as a brain region where $\mathrm{mTORC} 2$ signaling regulates DA-dependent behaviors by altering D2R signaling. D2R are clearly involved in schizophrenia, supported by the fact that typical antipsychotics that target D2R alleviate schizophrenic symptoms in humans (Chouinard et al., 1993; Min et al., 1993; Odou et al., 1996; Kasper et al., 1997). Furthermore, D2R antagonists attenuate schizophrenia-like phenotypes associated with striatal DA dysfunction in animal models (Cazorla et al., 2014). Here, we show that aberrant mTORC2 signaling in the dorsal striatum is sufficient to alter fundamental DA-dependent behaviors in mice. Furthermore, we demonstrate that reduction of mTORC2 function influences DA levels in the dorsal striatum and causes abnormal D2R signaling that leads to aberrant phosphorylation of ERK1/2, ultimately supporting the observed basal and AMPHinduced hyperactivity in the $\mathrm{KO}$ animals.

\section{Translational relevance}

Our prior findings reveal that nRictor KO mice have altered cortical DA neurotransmission associated with impaired prepulse inhibition (Siuta et al., 2010). In addition to cortical circuits, dysregulated striatal DA neurotransmission is also thought to be fundamental to the etiology of schizophrenia (Davis et al., 1991; Abi-Dargham et al., 2000; Howes and Kapur, 2009). Pivotal evidence supporting the DA hypothesis of schizophrenia stemmed from studies investigating psychotogenic effects of psychostimulants (Lieberman et al., 1987). Psychostimulants, including AMPH, disrupt striatal DA homeostasis (Rebec, 2006). Importantly, they were shown to cause paranoia and psychosis in healthy individuals, and further exacerbate psychoses in schizophrenic patients (Lieberman et al., 1987). Imaging studies implicate the dorsal striatum in AMPH responses in both healthy humans and patients with schizophrenia (Weinberger and Laruelle, 2002). This study enhances our understanding of how metabolic signaling via mTORC2 can influence DA neurotransmission in brain and reveals that $\mathrm{mTORC} 2$ is a pivotal regulator of striatal DA neurotransmission and AMPH action. Our data also support dysfunction of mTORC2 signaling as a possible mechanism underlying the etiology of schizophrenia.

\section{References}

Abi-Dargham A, Rodenhiser J, Printz D, Zea-Ponce Y, Gil R, Kegeles LS Weiss R, Cooper TB, Mann JJ, Van Heertum RL, Gorman JM, Laruelle M (2000) Increased baseline occupancy of D2 receptors by dopamine in schizophrenia. Proc Natl Acad Sci USA 97:8104-8109. CrossRef Medline

Andrews CD, Fernando JC, Curzon G (1982) Differential involvement of dopamine-containing tracts in 5-hydroxytryptamine-dependent behaviours caused by amphetamine in large doses. Neuropharmacology 21:6368. CrossRef Medline

Aschauer DF, Kreuz S, Rumpel S (2013) Analysis of transduction efficiency, tropism and axonal transport of AAV serotypes 1, 2, 5, 6, 8 and 9 in the mouse brain. PLoS One 8:e76310. CrossRef Medline

Bardo MT, Bowling SL, Pierce RC (1990) Changes in locomotion and dopamine neurotransmission following amphetamine, haloperidol, and 
exposure to novel environmental stimuli. Psychopharmacology 101:338343. CrossRef Medline

Bateup HS, Santini E, Shen W, Birnbaum S, Valjent E, Surmeier DJ, Fisone G, Nestler EJ, Greengard P (2010) Distinct subclasses of medium spiny neurons differentially regulate striatal motor behaviors. Proc Natl Acad Sci U S A 107:14845-14850. CrossRef Medline

Besusso D, Geibel M, Kramer D, Schneider T, Pendolino V, Picconi B, Calabresi P, Bannerman DM, Minichiello L (2013) BDNF-TrkB signaling in striatopallidal neurons controls inhibition of locomotor behavior. Nat Commun 4:2031. CrossRef Medline

Birkmayer W, Hornykiewicz O (1961) [The L-3,4-dioxyphenylalanine (DOPA)-effect in Parkinson-akinesia]. Wien Klin Wochenschr 73:787788. Medline

Bolan EA, Kivell B, Jaligam V, Oz M, Jayanthi LD, Han Y, Sen N, Urizar E, Gomes I, Devi LA, Ramamoorthy S, Javitch JA, Zapata A, Shippenberg TS (2007) D2 receptors regulate dopamine transporter function via an extracellular signal-regulated kinases 1 and 2-dependent and phosphoinositide 3 kinase-independent mechanism. Mol Pharmacol 71:1222-1232. CrossRef Medline

Brunelin J, Fecteau S, Suaud-Chagny MF (2013) Abnormal striatal dopamine transmission in schizophrenia. Curr Med Chem 20:397-404. CrossRef Medline

Butcher SP, Fairbrother IS, Kelly JS, Arbuthnott GW (1988) Amphetamineinduced dopamine release in the rat striatum: an in vivo microdialysis study. J Neurochem 50:346-355. CrossRef Medline

Cai G, Zhen X, Uryu K, Friedman E (2000) Activation of extracellular signal-regulated protein kinases is associated with a sensitized locomotor response to $\mathrm{D}(2)$ dopamine receptor stimulation in unilateral 6-hydroxydopamine-lesioned rats. J Neurosci 20:1849-1857. Medline

Carr GD, White NM (1984) The relationship between stereotypy and memory improvement produced by amphetamine. Psychopharmacology 82 : 203-209. CrossRef Medline

Carvelli L, Morón JA, Kahlig KM, Ferrer JV, Sen N, Lechleiter JD, LeebLundberg LM, Merrill G, Lafer EM, Ballou LM, Shippenberg TS, Javitch JA, Lin RZ, Galli A (2002) PI 3-kinase regulation of dopamine uptake. J Neurochem 81:859-869. CrossRef Medline

Cazorla M, de Carvalho FD, Chohan MO, Shegda M, Chuhma N, Rayport S, Ahmari SE, Moore H, Kellendonk C (2014) Dopamine D2 receptors regulate the anatomical and functional balance of basal ganglia circuitry. Neuron 81:153-164. CrossRef Medline

Chouinard G, Jones B, Remington G, Bloom D, Addington D, MacEwan GW, Labelle A, Beauclair L, Arnott W (1993) A Canadian multicenter placebo-controlled study of fixed doses of risperidone and haloperidol in the treatment of chronic schizophrenic patients. J Clin Psychopharmacol 13:25-40. Medline

Clapcote SJ, Lipina TV, Millar JK, Mackie S, Christie S, Ogawa F, Lerch JP, Trimble K, Uchiyama M, Sakuraba Y, Kaneda H, Shiroishi T, Houslay MD, Henkelman RM, Sled JG, Gondo Y, Porteous DJ, Roder JC (2007) Behavioral phenotypes of Discl missense mutations in mice. Neuron 54:387-402. CrossRef Medline

Cotzias GC, Van Woert MH, Schiffer LM (1967) Aromatic amino acids and modification of parkinsonism. N Engl J Med 276:374-379. CrossRef Medline

Damanhuri HA, Burke PG, Ong LK, Bobrovskaya L, Dickson PW, Dunkley PR, Goodchild AK (2012) Tyrosine hydroxylase phosphorylation in catecholaminergic brain regions: a marker of activation following acute hypotension and glucoprivation. PLoS One 7:e50535. CrossRef Medline

Davis KL, Klar H, Coyle JT (1991) Foundations of psychiatry. Philadelphia: Saunders.

Daws LC, Avison MJ, Robertson SD, Niswender KD, Galli A, Saunders C (2011) Insulin signaling and addiction. Neuropharmacology 61:11231128. CrossRef Medline

Dewar KM, Soghomonian JJ, Bruno JP, Descarries L, Reader TA (1990) Elevation of dopamine D2 but not D1 receptors in adult rat neostriatum after neonatal 6-hydroxydopamine denervation. Brain Res 536:287-296. CrossRef Medline

Doolen S, Zahniser NR (2001) Protein tyrosine kinase inhibitors alter human dopamine transporter activity in Xenopus oocytes. J Pharmacol Exp Ther 296:931-938. Medline

Durieux PF, Bearzatto B, Guiducci S, Buch T, Waisman A, Zoli M, Schiffmann SN, de Kerchove d'Exaerde A (2009) D2R striatopallidal neurons inhibit both locomotor and drug reward processes. Nat Neurosci 12:393395. CrossRef Medline

Durieux PF, Schiffmann SN, de Kerchove d'Exaerde A (2012) Differential regulation of motor control and response to dopaminergic drugs by $\mathrm{D} 1 \mathrm{R}$ and D2R neurons in distinct dorsal striatum subregions. EMBO J 31:640 653. CrossRef Medline

Easton RM, Cho H, Roovers K, Shineman DW, Mizrahi M, Forman MS, Lee VM, Szabolcs M, de Jong R, Oltersdorf T, Ludwig T, Efstratiadis A, Birnbaum MJ (2005) Role for Akt3/protein kinase Bgamma in attainment of normal brain size. Mol Cell Biol 25:1869-1878. CrossRef Medline

Emamian ES, Hall D, Birnbaum MJ, Karayiorgou M, Gogos JA (2004) Convergent evidence for impaired AKT1-GSK3beta signaling in schizophrenia. Nat Genet 36:131-137. CrossRef Medline

Espana RA, Jones SR (2013) Presynaptic dopamine modulation by stimulant self-administration. Front Biosci 5:261-276. Medline

Fischer E, Heller B (1967) Antagonic effects of cocaine and adrenaline on the psychomotor activity of mice. Acta Physiol Lat Am 17:118-119. Medline

Fischer JF, Cho AK (1979) Chemical release of dopamine from striatal homogenates: evidence for an exchange diffusion model. J Pharmacol Exp Ther 208:203-209. Medline

Franke TF (2008) PI3K/Akt: getting it right matters. Oncogene 27:64736488. CrossRef Medline

Gainetdinov RR, Mohn AR, Caron MG (2001) Genetic animal models: focus on schizophrenia. Trends Neurosci 24:527-533. CrossRef Medline

Garcia BG, Wei Y, Moron JA, Lin RZ, Javitch JA, Galli A (2005) Akt is essential for insulin modulation of amphetamine-induced human dopamine transporter cell-surface redistribution. Mol Pharmacol 68:102-109. CrossRef Medline

Gerhardt GA, Hoffman AF (2001) Effects of recording media composition on the responses of Nafion-coated carbon fiber microelectrodes measured using high-speed chronoamperometry. J Neurosci Methods 109: 13-21. CrossRef Medline

Goldstein M, Battista AF, Miyamoto T (1975) Modification of involuntary movements by centrally acting drugs. Adv Neurol 9:299-305. Medline

Hamilton PJ, Belovich AN, Khelashvili G, Saunders C, Erreger K, Javitch JA, Sitte HH, Weinstein H, Matthies HJ, Galli A (2014) PIP2 regulates psychostimulant behaviors through its interaction with a membrane protein. Nat Chem Biol 10:582-589. CrossRef Medline

Hoffman AF, Gerhardt GA (1999) Differences in pharmacological properties of dopamine release between the substantia nigra and striatum: an in vivo electrochemical study. J Pharmacol Exp Ther 289:455-463. Medline

Hornykiewicz O (1966) Dopamine (3-hydroxytyramine) and brain function. Pharmacol Rev 18:925-964. Medline

Howes OD, Kapur S (2009) The dopamine hypothesis of schizophrenia: version III-the final common pathway. Schizophr Bull 35:549-562. CrossRef Medline

Johnson PM, Kenny PJ (2010) Dopamine D2 receptors in addiction-like reward dysfunction and compulsive eating in obese rats. Nat Neurosci 13:635-641. CrossRef Medline

Kahlig KM, Binda F, Khoshbouei H, Blakely RD, McMahon DG, Javitch JA, Galli A (2005) Amphetamine induces dopamine efflux through a dopamine transporter channel. Proc Natl Acad Sci U S A 102:3495-3500. CrossRef Medline

Kasper S, Barnas C, Heiden A, Volz HP, Laakmann G, Zeit H, Pfolz H (1997) Pramipexole as adjunct to haloperidol in schizophrenia: safety and efficacy. Eur Neuropsychopharmacol 7:65-70. CrossRef Medline

Kellendonk C, Simpson EH, Polan HJ, Malleret G, Vronskaya S, Winiger V, Moore H, Kandel ER (2006) Transient and selective overexpression of dopamine D2 receptors in the striatum causes persistent abnormalities in prefrontal cortex functioning. Neuron 49:603-615. CrossRef Medline

Kelly PH, Seviour PW, Iversen SD (1975) Amphetamine and apomorphine responses in the rat following 6-OHDA lesions of the nucleus accumbens septi and corpus striatum. Brain Res 94:507-522. CrossRef Medline

Kramer PF, Christensen CH, Hazelwood LA, Dobi A, Bock R, Sibley DR, Mateo Y, Alvarez VA (2011) Dopamine D2 receptor overexpression alters behavior and physiology in Drd2-EGFP mice. J Neurosci 31:126-132. CrossRef Medline

Kreitzer AC, Malenka RC (2008) Striatal plasticity and basal ganglia circuit function. Neuron 60:543-554. CrossRef Medline

Krishnan V, Han MH, Mazei-Robison M, Iñiguez SD, Ables JL, Vialou V, Berton O, Ghose S, Covington HE 3rd, Wiley MD, Henderson RP, Neve 
RL, Eisch AJ, Tamminga CA, Russo SJ, Bolaños CA, Nestler EJ (2008) AKT signaling within the ventral tegmental area regulates cellular and behavioral responses to stressful stimuli. Biol Psychiatry 64:691-700. CrossRef Medline

Kristensen AS, Andersen J, Jørgensen TN, Sørensen L, Eriksen J, Loland CJ, Strømgaard K, Gether U (2011) SLC6 neurotransmitter transporters: structure, function, and regulation. Pharmacol Rev 63:585-640. CrossRef Medline

Langston JW, Ballard PA Jr (1983) Parkinson's disease in a chemist working with 1-methyl-4-phenyl-1,2,5,6-tetrahydropyridine. N Engl J Med 309: 310. CrossRef Medline

Lieberman JA, Kane JM, Alvir J (1987) Provocative tests with psychostimulant drugs in schizophrenia. Psychopharmacology 91:415-433. CrossRef Medline

Lipina TV, Niwa M, Jaaro-Peled H, Fletcher PJ, Seeman P, Sawa A, Roder JC (2010) Enhanced dopamine function in DISC1-L100P mutant mice: implications for schizophrenia. Genes Brain Behav 9:777-789. CrossRef Medline

Lu XH, Dwyer DS (2005) Second-generation antipsychotic drugs, olanzapine, quetiapine, and clozapine enhance neurite outgrowth in PC12 cells via PI3K/AKT, ERK, and pertussis toxin-sensitive pathways. J Mol Neurosci 27:43-64. CrossRef Medline

Luo Y, Kokkonen GC, Wang X, Neve KA, Roth GS (1998) D2 dopamine receptors stimulate mitogenesis through pertussis toxin-sensitive $G$ proteins and Ras-involved ERK and SAP/JNK pathways in rat C6-D2L glioma cells. J Neurochem 71:980-990. CrossRef Medline

Lute BJ, Khoshbouei H, Saunders C, Sen N, Lin RZ, Javitch JA, Galli A (2008) PI3K signaling supports amphetamine-induced dopamine efflux. Biochem Biophys Res Commun 372:656-661. CrossRef Medline

Marazziti D, Golini E, Mandillo S, Magrelli A, Witke W, Matteoni R, Tocchini-Valentini GP (2004) Altered dopamine signaling and MPTP resistance in mice lacking the Parkinson's disease-associated GPR37/ parkin-associated endothelin-like receptor. Proc Natl Acad Sci U S A 101: 10189-10194. CrossRef Medline

Markakis EA, Vives KP, Bober J, Leichtle S, Leranth C, Beecham J, Elsworth JD, Roth RH, Samulski RJ, Redmond DE Jr (2010) Comparative transduction efficiency of AAV vector serotypes 1-6 in the substantia nigra and striatum of the primate brain. Mol Ther 18:588-593. CrossRef Medline

Mazei-Robison MS, Koo JW, Friedman AK, Lansink CS, Robison AJ, Vinish M, Krishnan V, Kim S, Siuta MA, Galli A, Niswender KD, Appasani R, Horvath MC, Neve RL, Worley PF, Snyder SH, Hurd YL, Cheer JF, Han MH, Russo SJ, et al. (2011) Role for mTOR signaling and neuronal activity in morphine-induced adaptations in ventral tegmental area dopamine neurons. Neuron 72:977-990. CrossRef Medline

Min SK, Rhee CS, Kim CE, Kang DY (1993) Risperidone versus haloperidol in the treatment of chronic schizophrenic patients: a parallel group double-blind comparative trial. Yonsei Med J 34:179-190. CrossRef Medline

Narendran R, Martinez D (2008) Cocaine abuse and sensitization of striatal dopamine transmission: a critical review of the preclinical and clinical imaging literature. Synapse 62:851-869. CrossRef Medline

Nestler EJ (2005) Is there a common molecular pathway for addiction? Nat Neurosci 8:1445-1449. CrossRef Medline

Nestler EJ (2013) Cellular basis of memory for addiction. Dial Clin Neurosci 15:431-443. Medline

Nicodemus KK, Marenco S, Batten AJ, Vakkalanka R, Egan MF, Straub RE, Weinberger DR (2008) Serious obstetric complications interact with hypoxia-regulated/vascular-expression genes to influence schizophrenia risk. Mol Psychiatry 13:873-877. CrossRef Medline

Nicodemus KK, Law AJ, Radulescu E, Luna A, Kolachana B, Vakkalanka R, Rujescu D, Giegling I, Straub RE, McGee K, Gold B, Dean M, Muglia P, Callicott JH, Tan HY, Weinberger DR (2010) Biological validation of increased schizophrenia risk with NRG1, ERBB4, and AKT1 epistasis via functional neuroimaging in healthy controls. Arch Gen Psychiatry 67: 991-1001. CrossRef Medline

Niswender KD, Daws LC, Avison MJ, Galli A (2011) Insulin regulation of monoamine signaling: pathway to obesity. Neuropsychopharmacology 36:359-360. CrossRef Medline

Odou P, Vaiva G, Luyckx M, Brunet C, Dine T, Gressier B, Cazin M, Cazin JC (1996) Neuroleptic monitoring: relation between antipsychotic efficiency and radioreceptor assay of serum haloperidol. Eur J Clin Pharmacol 50:357-363. CrossRef Medline
Oh WJ, Jacinto E (2011) mTOR complex 2 signaling and functions. Cell Cycle 10:2305-2316. CrossRef Medline

Owens WA, Williams JM, Saunders C, Avison MJ, Galli A, Daws LC (2012) Rescue of dopamine transporter function in hypoinsulinemic rats by a D2 receptor-ERK-dependent mechanism. J Neurosci 32:2637-2647. CrossRef Medline

Porrino LJ, Lucignani G, Dow-Edwards D, Sokoloff L (1984) Correlation of dose-dependent effects of acute amphetamine administration on behavior and local cerebral metabolism in rats. Brain Res 307:311-320. CrossRef Medline

Radja F, el Mansari M, Soghomonian JJ, Dewar KM, Ferron A, Reader TA, Descarries L (1993) Changes of D1 and D2 receptors in adult rat neostriatum after neonatal dopamine denervation: quantitative data from ligand binding, in situ hybridization and iontophoresis. Neuroscience 57: 635-648. CrossRef Medline

Rebec GV (2006) Behavioral electrophysiology of psychostimulants. Neuropsychopharmacology 31:2341-2348. CrossRef Medline

Robertson SD, Matthies HJ, Owens WA, Sathananthan V, Christianson NS, Kennedy JP, Lindsley CW, Daws LC, Galli A (2010) Insulin reveals Akt signaling as a novel regulator of norepinephrine transporter trafficking and norepinephrine homeostasis. J Neurosci 30:11305-11316. CrossRef Medline

Salahpour A, Ramsey AJ, Medvedev IO, Kile B, Sotnikova TD, Holmstrand E, Ghisi V, Nicholls PJ, Wong L, Murphy K, Sesack SR, Wightman RM, Gainetdinov RR, Caron MG (2008) Increased amphetamine-induced hyperactivity and reward in mice overexpressing the dopamine transporter. Proc Natl Acad Sci U S A 105:4405-4410. CrossRef Medline

Salvatore MF (2014) ser31 tyrosine hydroxylase phosphorylation parallels differences in dopamine recovery in nigrostriatal pathway following 6-OHDA lesion. J Neurochem 129:548-558. CrossRef Medline

Salvatore MF, Pruett BS (2012) Dichotomy of tyrosine hydroxylase and dopamine regulation between somatodendritic and terminal field areas of nigrostriatal and mesoaccumbens pathways. PLoS One 7:e29867. CrossRef Medline

Salvatore MF, Pruett BS, Spann SL, Dempsey C (2009) Aging reveals a role for nigral tyrosine hydroxylase ser31 phosphorylation in locomotor activity generation. PLoS One 4:e8466. CrossRef Medline

Schulingkamp RJ, Pagano TC, Hung D, Raffa RB (2000) Insulin receptors and insulin action in the brain: review and clinical implications. Neurosci Biobehav Rev 24:855-872. CrossRef Medline

Sharp T, Zetterström T, Ljungberg T, Ungerstedt U (1987) A direct comparison of amphetamine-induced behaviours and regional brain dopamine release in the rat using intracerebral dialysis. Brain Res 401:322-330. CrossRef Medline

Shiota C, Woo JT, Lindner J, Shelton KD, Magnuson MA (2006) Multiallelic disruption of the rictor gene in mice reveals that mTOR complex 2 is essential for fetal growth and viability. Dev Cell 11:583-589. CrossRef Medline

Simpson EH, Kellendonk C, Kandel E (2010) A possible role for the striatum in the pathogenesis of the cognitive symptoms of schizophrenia. Neuron 65:585-596. CrossRef Medline

Siuta MA, Robertson SD, Kocalis H, Saunders C, Gresch PJ, Khatri V, Shiota C, Kennedy JP, Lindsley CW, Daws LC, Polley DB, Veenstra-Vanderweele J, Stanwood GD, Magnuson MA, Niswender KD, Galli A (2010) Dysregulation of the norepinephrine transporter sustains cortical hypodopaminergia and schizophrenia-like behaviors in neuronal rictor null mice. PLoS Biol 8:e1000393. CrossRef Medline

Speed NK, Matthies HJ, Kennedy JP, Vaughan RA, Javitch JA, Russo SJ, Lindsley CW, Niswender K, Galli A (2010) Akt-dependent and isoformspecific regulation of dopamine transporter cell surface expression. ACS Chem Neurosci 1:476-481. CrossRef Medline

Speed N, Saunders C, Davis AR, Owens WA, Matthies HJ, Saadat S, Kennedy JP, Vaughan RA, Neve RL, Lindsley CW, Russo SJ, Daws LC, Niswender KD, Galli A (2011a) Impaired striatal Akt signaling disrupts dopamine homeostasis and increases feeding. PLoS One 6:e25169. CrossRef Medline

Speed N, Saunders C, Davis A, Owens W, Matthies H, Saadat S, Kennedy J, Vaughan R, Neve R, Lindsley C, Russo S, Daws L, Niswender K, Galli A (2011b) Impaired striatal Akt signaling disrupts dopamine homeostasis and increases feeding. PLoS One 6:1-10. CrossRef

Sulzer D, Sonders MS, Poulsen NW, Galli A (2005) Mechanisms of neurotransmitter release by amphetamines: a review. Prog Neurobiol 75: 406-433. CrossRef Medline 
Tan HY, Chen AG, Chen Q, Browne LB, Verchinski B, Kolachana B, Zhang F, Apud J, Callicott JH, Mattay VS, Weinberger DR (2012) Epistatic interactions of AKT1 on human medial temporal lobe biology and pharmacogenetic implications. Mol Psychiatry 17:1007-1016. CrossRef Medline

Thomas DM, Francescutti-Verbeem DM, Kuhn DM (2008) The newly synthesized pool of dopamine determines the severity of methamphetamineinduced neurotoxicity. J Neurochem 105:605-616. CrossRef Medline

Ungerstedt U (1968) 6-Hydroxy-dopamine induced degeneration of central monoamine neurons. Eur J Pharmacol 5:107-110. CrossRef Medline

Ungerstedt U, Pycock C (1974) Functional correlates of dopamine neurotransmission. Bull Schweiz Akad Med Wiss 30:44-55. Medline

van der Heide LP, Ramakers GM, Smidt MP (2006) Insulin signaling in the central nervous system: learning to survive. Prog Neurobiol 79:205-221. CrossRef Medline

Wang C, Buck DC, Yang R, Macey TA, Neve KA (2005) Dopamine D2 receptor stimulation of mitogen-activated protein kinases mediated by cell type-dependent transactivation of receptor tyrosine kinases. J Neurochem 93:899-909. CrossRef Medline

Wang GJ, Volkow ND, Logan J, Pappas NR, Wong CT, Zhu W, Netusil N, Fowler JS (2001) Brain dopamine and obesity. Lancet 357:354-357. CrossRef Medline

Wang GJ, Volkow ND, Fowler JS (2002) The role of dopamine in motivation for food in humans: implications for obesity. Expert Opin Ther Targets 6:601-609. CrossRef Medline

Weinberger D, Laruelle M (2002) Neurochemical and neurophramacological imaging in schizophrenia. In: Neuropsychopharmacology: the fifth generation of progress (Davis K, Charney D, Coyle J, Nemeroff C, eds). Philadelphia: Lippincott Williams and Wilkins.

Williams JM, Owens WA, Turner GH, Saunders C, Dipace C, Blakely RD, France CP, Gore JC, Daws LC, Avison MJ, Galli A (2007) Hypoinsulinemia regulates amphetamine-induced reverse transport of dopamine. PLoS Biol 5:2369-2378. Medline 